\title{
Factors Influencing Nutritional Status of Children Under Five Years in Coastal Area at Panarukan Sub-District Situbondo Regency
}

\author{
$1^{\text {st }}$ Kuspriyanto \\ Department of Geography Education \\ Faculty of Social Sciences and Law \\ Universitas Negeri Surabaya \\ Surabaya, Indonesia \\ kuspriyanto@unesa.ac.id
}

\author{
$2^{\text {nd }}$ Sulistinah \\ Department of Geography Education \\ Faculty of Social Sciences and Law \\ Universitas Negeri Surabaya \\ Surabaya, Indonesia \\ sulistinah@unesa.ac.id
}

\author{
$3^{\text {rd }}$ Ita Mardiani Zain \\ Department of Geography Education \\ Faculty of Social Sciences and Law \\ Universitas Negeri Surabaya \\ Surabaya, Indonesia \\ itamardiani@unesa.ac.id
}

\begin{abstract}
Kilensari and Gelung village are coastal area in Panarukan subdistrict which have different number of malnutrition in children under five years. Panarukan subdistrict is sub district with the highest number of malnutrition in children under five years in Situbondo regency. This study was conducted to know the influence among duration of breastfeeding, number of family member, family income, mother's knowledge on children nutritional status and also to know which are among the five most influential on the chidren nutritional status. 54 mothers who have malnutrition child as the case subject and 54 mothers who have child with proper nutrition as the control subject were used in this study. The way of submitting data were interviewing and documentating. The observation use case control method through count odd ratio (OR). Data obtained were analyzed by Chi-square and multiple logistic regression. Results showed the significant factor that influence children nutritional status in Kilensari and Gelung village were family income $(p=0.014$ and $O R=4.75)$ and mother's knowlegde $(p=0.011$ and $O R=$ 5.5) and according to multiple logistic regression, the most influence factor on children nutritional status in Kilensari and Gelung village was mother's knowlegde $(\mathbf{p}=\mathbf{0 . 0 0 7})$.. (Abstract)
\end{abstract}

\section{Keywords - children nutritional status, malnutrition}

\section{INTRODUCTION}

Population in a country becomes the most important factor in the implementation of development because it becomes the subject and object of development. The development of a country will be successful if it has a qualified population, healthy intelligent and productive. Although the country has abundant natural resources, but without qualified and resilient human resources, the country will not be able to develop itself. One of indicators of the success country in building human resources is the Human Development Index (HDI). The HDI in 2011 covered 187 countries and Indonesia was ranked 124th, putting Indonesia below the regional average [1].

According to data from [2], nutritional problems in Situbondo is a high prevalance, there were 587 malnutrition in children under five years. The main nutritional problems are many children under five years who are under the red line. Table 1 presents the number of malnutrition children under five years in Situbondo regency, Panarukan sub district is the highest prevalence of malnutrition in children under five years compared to other sub-districts and far above the national standard of malnutrition cases.

Panarukan sub-district consists of 8 villages namely Sumberkolak, Wringin Anom, Paowan, Kilensari, Peleyan, Balwet and Gelung village with different number of malnutrition in children under five years (Tabel 2). According to data in Table 2, Kilensari village is the highest number of malnutrition in children under five years and Gelung village is the lowest. Kilensari and Gelung village is coastal area whose livelihoods are fishermen. They have similar characteristics in economic, demographic and morphological issues.

Table 1. Number of children under five malnutrition in Situbondo

\begin{tabular}{|c|c|c|c|}
\hline Subdistrict & $\begin{array}{l}\text { Number of } \\
\text { children } \\
\text { under five }\end{array}$ & $\begin{array}{c}\text { Malnutrition } \\
\text { Children } \\
\text { under five }\end{array}$ & $\begin{array}{c}\text { Percentage } \\
(\%)\end{array}$ \\
\hline Sumbermalang & 2165 & 35 & 6 \\
\hline Jatibanteng & 1741 & 43 & 7.3 \\
\hline Banyuglugur & 1694 & 25 & 4.2 \\
\hline Besuki & 4550 & 31 & 5.3 \\
\hline Suboh & 2015 & 27 & 4 \\
\hline Mlandingan & 1845 & 33 & 5.6 \\
\hline Bungatan & 1903 & 36 & 6 \\
\hline Kendit & 2248 & 51 & 8.7 \\
\hline Panarukan & 3859 & 69 & 12 \\
\hline Situbondo & 3810 & 17 & 2.9 \\
\hline Mangaran & 4869 & 57 & 9.7 \\
\hline Panji & 2415 & 27 & 5 \\
\hline Kapongan & 2929 & 45 & 8 \\
\hline Arjasa & 3228 & 51 & 8.7 \\
\hline Jangkar & 2799 & 15 & 2.6 \\
\hline Asembagus & 3849 & 11 & 2 \\
\hline Banyuputih & 3319 & 14 & 2 \\
\hline Amount & 49211 & 587 & 100 \\
\hline
\end{tabular}

Source: [2] 
Table 2. Number of children under five malnutrition in Paanukan

\begin{tabular}{|l|c|c|}
\hline Village & $\begin{array}{c}\text { Number of malnutrition } \\
\text { children under five }\end{array}$ & $\begin{array}{c}\text { Percentage } \\
(\%)\end{array}$ \\
\hline Sumberkolak & 11 & 16 \\
\hline Wringin Anom & 2 & 3 \\
\hline Paowan & 5 & 7.2 \\
\hline Kilensari & 21 & 30.4 \\
\hline Peleyan & 10 & 14.4 \\
\hline Alasmalang & 6 & 9 \\
\hline Duwet & 8 & 12 \\
\hline Gelung & 6 & 8 \\
\hline Amount & 69 & 100 \\
\hline
\end{tabular}

Source : [3]

Malnutrition occured in all villages in Panarukan sub-district. This should be solved immediately because children below five years is susceptible to nutrition. Nutrition is very important for growth and sophistication, so it is necessary to monitor and fulfill good nutrition. From the description above, it is very interested to conduct a study related to the factors that influence nutritional status of children under five years in the coastal area at Panarukan sub-district Situbondo Regency.

\section{RESEARCH METODS}

This study is an analytic survey method. Then analyze the correlation dynamics between phenomena, either between risk factors with the effect factor or between risk factors through hypothesis testing. This study used retrospective approach with case control research design that is identified the effect factor (dependent variable) firstly, and risk factor (independent variable) is identified then by controlling control variable that is education and mother's occupation. The study was conducted in Kilensari and Gelung village as a coastal area in Panarukan subdistrict Situbondo Regency. The case subjects were all mothers who have malnutrition children under five years $(n=54)$, and control subjects were selected from mothers who have proper nutrient children under five years as many as 54 mothers.

Sources data were primary and secondary data. Primary data were obtained from interview the respondents regarding duration of breastfeeding, number of family member, family income, mother's knowledge. The way of submitting data were interviewing and documentating. Data obtained was analyzed statistically by using :

a. Chi-square test was performed with SPSS for windows program with Chi-Square Test (X2) to determine the effect of duration of breastfeeding, number of familr, family income and mother's knowledge on malnutrition status of children under five years.

b. Multiple logistic regression test was performed with SPSS program to determine the most dominant influence (significant) between variables on malnutrition status of children under five years. Multiple Logistic regression using the following " 1 ":

$$
p(x)=\frac{1}{1+e^{-g^{(x)}}}
$$

$$
g(x)=\beta_{0}+\beta_{1} \cdot x_{1}+\beta_{2} \cdot x_{2}+\beta_{3} \cdot x_{3}+\beta_{4} \cdot x_{4}
$$

were :

$\begin{array}{lll}\boldsymbol{\beta}_{0} & : & \text { intercept parameters } \\ \boldsymbol{\beta}_{1}-\boldsymbol{\beta}_{4} & : & \text { regression coefficient parameters } \\ e & : & \text { exponential } \\ x_{1} & : & \text { duration of breastfeeding factor } \\ x_{2} & : & \text { number of family member factor } \\ x_{3} & : & \text { family income factor } \\ x_{4} & : \text { mother's knowledge factor }\end{array}$

\section{RESULTS AND DISCUSSION}

\section{A. Data Analysis Using the Chi-Square test}

Define abbreviations and acronyms the first time they are used in the text, even after they have been defined in the abstract. Abbreviations such as IEEE, SI, MKS, CGS, sc, dc, and arms do not have to be defined. Do not use abbreviations in the title or heads unless they are unavoidable.

\section{1) Duration of breastfeeding}

Duration of breastfeeding in this study is the period of breastfeeding to the baby. Based on the study about the influence of duration of breastfeeding on nutritional status of children under five years in Kilensari and Gelung villages (Tabel 3), it is known that the duration of breastfeeding less than 6 months is 35 respondents with the details 15 children are malnutrition children $(27.8 \%)$ and 20 children are in proper nutrition $(37.0 \%)$. While the duration of breastfeeding that longer than 6 months is 19 respondents with the details 12 children are malnutrition children $(22.2 \%)$ and 7 children are in proper nutrition $(13 \%)$.

Table 3. Influence of duration of breastfeeding on the nutritional status of children under five years in Kilensari and Gelung village

\begin{tabular}{|ll|l|l|l|l|l|l|}
\hline \multirow{2}{*}{$\begin{array}{l}\text { Duration } \\
\text { breastfeeding }\end{array}$} & \multicolumn{5}{|l|}{ Nutritional status } \\
\cline { 3 - 8 } & & \multicolumn{2}{|l|}{$\begin{array}{l}\text { malnutritio } \\
\mathrm{n}\end{array}$} & \multicolumn{2}{l|}{$\begin{array}{l}\text { Proper } \\
\text { nutrition }\end{array}$} & \multicolumn{2}{|l|}{ Total } \\
\cline { 3 - 8 } & $\mathrm{F}$ & $\%$ & $\mathrm{~F}$ & $\%$ & $\mathrm{~F}$ & $\%$ \\
\hline $\begin{array}{l}\text { Less than six } \\
\text { months }\end{array}$ & 15 & 27.8 & 20 & 37.0 & 35 & $\begin{array}{l}64 . \\
8\end{array}$ \\
\hline $\begin{array}{l}\text { More than six } \\
\text { months }\end{array}$ & 12 & 22.2 & 7 & 13.0 & 19 & $\begin{array}{l}35 . \\
2\end{array}$ \\
\hline $\begin{array}{l}\text { Amount } \\
X^{2}=1.299\end{array}$ & 27 & 50 & 27 & 50 & 54 & $\begin{array}{l}10 \\
0\end{array}$ \\
\hline
\end{tabular}

Source: Primary data (2017)

Based on Chi-Square test it can be seen that the value of $\mathrm{p}=0.254$ with the value of $\mathrm{X}^{2}=1.299 \mathrm{using}$ the degree of error $(\alpha)=0.05$ means the value $p>\alpha$ $(0.254>0.05)$. So it can be concluded that there is no significant influence between duration of breastfeeding on the nutritional status of children under five years in the coastal area of Panarukan sub-district, Situbondo regency.

This result is not in line with [4] which stated that the mother's nutritional condition has been influential since the baby is still in the womb, followed in the first months of breastfeeding. According [5] the nutritional status of children is also determined by maternal nutrition at the time of pregnancy. The period of 
pregnancy is the time when a woman maintains a lot more nutrient that is needed in the normal condition. Besides for the growth and development of the fetus in the womb. There is a very close relationship between maternal food sufficiency during pregnancy and the baby's nutritional condition after born.

Based on the facts on the field, some mothers choose not to breastfeed for work reasons. In addition, some mothers mother did not breastfeed exclusively but they were more giving formula milk for easy practical reasons. So, the longer the mother breastfeed the higher the nutrition of the child is fulfilled.

\section{2) Number of family member}

The number of family members is the number of family members who are being burdened with dependents in one family. Based on study about the influence of the number of family members on nutritional status of children under five years in Kilensari and Gelung villages (Table 4), it is known that the number of members under the average or $\leq 3$ as many as 18 respondents with the details 7 children are malnutrition children $(13.0 \%)$ and 11 children are in proper nutrition. While the number of family members above average $>3$ as many as 36 respondents with the details 20 children are malnutrition children $(37.0 \%)$ and 16 children are in proper nutrition (29.6\%).

Based on Chi-Square test it can be seen that $\mathrm{p}=$ 0.386 with value $X^{2}=0.750$ by using degree of error $(\alpha)=0.05$ mean value $p>\alpha(0.386>0.05)$. So it can be concluded that there is no significant influence between the number of family members on the nutritional status of children under five years in the coastal area Panarukan district Situbondo regency.

Table 4. Influence of number of a family member on the nutritional status of children under five years in Kilensari and Gelung village

\begin{tabular}{|l|c|c|c|c|c|c|}
\hline \multirow{2}{*}{$\begin{array}{c}\text { Number of family } \\
\text { member }\end{array}$} & \multicolumn{6}{c|}{ Nutritional status } \\
\cline { 2 - 8 } & $\begin{array}{c}\text { Malnutritio } \\
\mathrm{n}\end{array}$ & $\begin{array}{c}\text { Proper } \\
\text { nutrition }\end{array}$ & \multicolumn{2}{c|}{ Total } \\
\cline { 2 - 8 } & $\mathrm{F}$ & $\%$ & $\mathrm{~F}$ & $\%$ & $\mathrm{~F}$ & $\%$ \\
\hline Under average & 7 & 13.0 & 11 & 20.4 & 18 & 33.3 \\
\hline Above average & 20 & 37.0 & 16 & 29.6 & 36 & 66.7 \\
\hline Amount & 27 & 50 & 27 & 50 & 54 & 100 \\
\hline \multicolumn{3}{|c|}{$X^{2}=0.750$} & & \multicolumn{4}{c|}{$\mathrm{p}=0.386$} \\
\hline
\end{tabular}

Source: Primary data (2017)

The results are not in accordance with the opinion of [6] with stated that family food sources, especially those who are very poor, will be easier to meet food needs if that should be given in small amounts of food. Food is available for large families enough for half family, but not enough to prevent nutritional disorders in the family.

Based on interviews with respondents, the number of family members above average have a malnutrition child under five is higher. This is because of the low income so that the fulfillment of food less. Some people in Kilensari and Gelung village with livelihoods as fishermen have more than 3 family members. The respondents stated that low income as fishermen is only sufficient to meet daily needs. So, the more family members, the more will vary their activities, work, and tastes. So the number of family members associated with the fulfillment of nutritional needs that are influenced by food consumption.

\section{3) Family income}

Family income in this study is the money earned by father and mother in 1 month. Based on study about the influence of family income on the nutrition status of children under five years in Kilensari and Gelung villages (Table 5), it is known that the income of the family below the average or $\leq 1.054 .807$ as many as 26 respondents with the details 18 children are malnutrition children $(33.3 \%)$ and 8 children are in proper nutrition. (14.8\%). While the family income above average or $>1,054,807$ as many as 28 respondents with the details 9 children are malnutrition children $(16,7 \%)$ and 19 children are in proper nutrition $(35,2 \%)$.

Table 5. Influence of family income on the nutritional status of children under five years in Kilensari and Gelung village

\begin{tabular}{|l|c|c|c|c|c|c|}
\hline \multirow{2}{*}{$\begin{array}{l}\text { Family } \\
\text { income }\end{array}$} & \multicolumn{6}{|c|}{ Nutritional status } \\
\cline { 2 - 8 } & Malnutrition & $\begin{array}{c}\text { Proper } \\
\text { nutrition }\end{array}$ & \multicolumn{2}{c|}{ Total } \\
\cline { 2 - 8 } & $\mathrm{F}$ & $\%$ & $\mathrm{~F}$ & $\%$ & $\mathrm{~F}$ & $\%$ \\
\hline $\begin{array}{l}\text { Under } \\
\text { average }\end{array}$ & 18 & 33.3 & 8 & 14.8 & 26 & 48.1 \\
\hline $\begin{array}{l}\text { Diatas rata- } \\
\text { rata }\end{array}$ & 9 & 16.7 & 19 & 35.2 & 28 & 51.9 \\
\hline Amount & 27 & 50 & 27 & 50 & 54 & 100 \\
\hline \multicolumn{3}{|c|}{$X^{2}=6.008$} & & \multicolumn{5}{c|}{$\mathrm{p}=0.014$} \\
\hline
\end{tabular}

Source: Primary data (2017)

Based on Chi-Square test it can be seen that $\mathrm{p}=$ 0.014 with value $X^{2}=6,008$ by using degree of error $(\alpha)=0,05$ mean value $p<\alpha(0,014<0,05)$. So it can be concluded that there is a significant influence between family income on the nutritional status of children under five yearsin in the coastal area Panarukan Subdistrict, Situbondo Regency with Odd Ratio (OR) value:

$$
\frac{a x d}{b x c}=\frac{18 \times 19}{8 \times 9}=4,75
$$

The results of the Odd Ratio (OR) calculation showed that respondents who had a family income under average or $\leq 1.054 .807$ were more likely to have malnutrition children under five 4.75 times compared with respondents who had above average family income or> 1.054. 807.

This is similar to [7] said the poor will usually spend most of the income on food, while the rich will certainly be less than that amount. The portions for grain foods will decrease and for dairy foods will increase if families move to middle income. The higher the income, the greater in spending, including fruits, vegetables and other types of food. Thus, income is the factor that most determine the quantity and quality of 
food. There is a close relationship between income and nutrition, driven by the beneficial effect of increased income for the improvement of health and other family issues related to the state of nutrition.

\section{4) Mother's knowledge}

Mother's knowledge is everything that the mother knows about nutritious food, proper food processing and the nutrients needed by the children body. Based on research on the influence of mother's knowledge on the nutrition status of children under five years in Kilensari and Gelung villages (Table 6), it is known that the mother's knowledge below the average as many as 20 respondents with the details 15 children are malnutrition children $(27.8 \%)$ and 5 children are in proper nutrition (9.3\%). While the mother's knowledge above average as many as 34 respondents with the details that have malnourished children under 12 children are malnutrition children $(22.2 \%)$ and 22 children are in proper nutrition $(40.7 \%)$.

Table 6. Influence of mother's knowledge on the nutritional status of children under five years in Kilensari and Gelung village

\begin{tabular}{|l|c|c|c|c|c|c|}
\hline \multirow{2}{*}{$\begin{array}{l}\text { Mother's } \\
\text { knowledge }\end{array}$} & \multicolumn{6}{c|}{ Nutritional status } \\
\cline { 2 - 7 } & Malnutrition & $\begin{array}{c}\text { Proper } \\
\text { nutrition }\end{array}$ & \multicolumn{2}{c|}{ Total } \\
\cline { 2 - 7 } & $\mathrm{F}$ & $\%$ & $\mathrm{~F}$ & $\%$ & $\mathrm{~F}$ & $\%$ \\
\hline $\begin{array}{l}\text { Under } \\
\text { average }\end{array}$ & 15 & 27.8 & 5 & 9.3 & 20 & 37.0 \\
\hline $\begin{array}{l}\text { Above } \\
\text { average }\end{array}$ & 12 & 22.2 & 22 & 40.7 & 34 & 63.0 \\
\hline amount & 27 & 50 & 27 & 50 & 54 & 100 \\
\hline \multicolumn{6}{|c|}{$X^{2}=6.432$} & \multicolumn{5}{c|}{$\mathrm{p}=0.011$} \\
\hline
\end{tabular}

Source: Primary data (2017)

Based on Chi-Square test it can be seen that $\mathrm{p}=0.011$ with value $\mathrm{X}^{2}=6.432$ by using degree of error $(\alpha)=0.05$ mean value $p<\alpha(0.011$ $<0.05)$. So it can be concluded that there is a significant influence between mother's knowledge on the nutritional status of children under five in Panarukan subdistrict, Situbondo regency with Odd Ratio (OR) value:

$$
\frac{a x d}{b x c}=\frac{15 \times 22}{5 \times 12}=\frac{330}{60}=5,5
$$

The results of the Odd Ratio (OR) calculation showed that respondents who had knowledge under average or $\leq 14$ were more likely to have malnutrition children under five 5.5 times than those who had knowledge above average or> 14.

According to [8] a good knowledge of nutrient causes a person able to formulate a good diet for consumption. The more the knowledge of nutrient, the more likely it is to calculate the amount of food for consumption. This opinion is also supported by [6] that the lack of knowledge and the wrong concept of food needs is common in every country. Poorness and lack of food availability are important factors in malnutrition, another important cause of nutritional disorders is lack of knowledge about nutrition and knowing the ability to apply information in daily life.

The fact in the field some of the mothers are less concerned about how to cook and process the food properly and less understood about the nutritional content of the food they eat. In Kilensari and Gelung village as coastal area lack of counseling about good nutrition for children under five years, and otherwise, if there is counseling some mother did not come for job reason. Thus, the higher the knowledge of a mother, the higher will be in receiving information about nutrition.

\section{B. Data Analysis Using Multiple Logistic Regression Test}

In this analysis, a children under five years with malnutrition status is given a score of 0 , whereas children under five years with proper nutritional status are given a score of 1 , so if depicted with curve $S$ as presented in Fig.1, then the value $\mathrm{p}=0$ to children under five years with malnutrition status and p-value $=$ 1 to children under five years who have good nutrition.

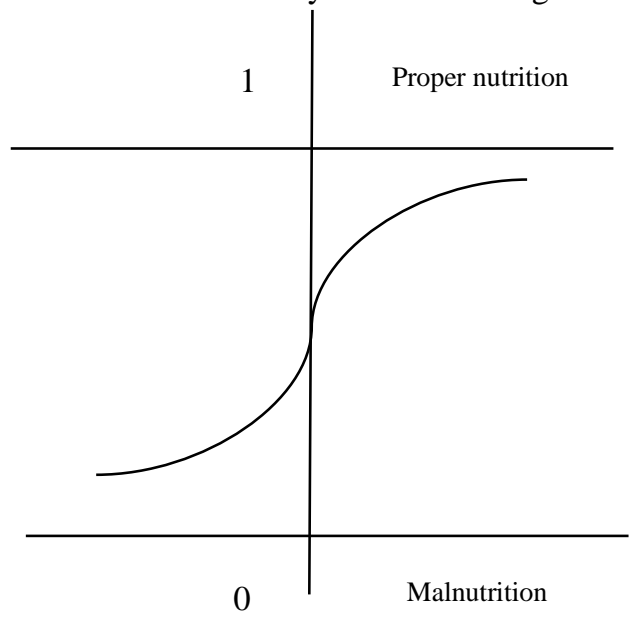

Fig 1. Case Probability Curve

Independent variables in this study are a duration of breastfeeding, number of family members, family income and mother's knowledge, while dependent variable nutritional status that is formed into the variable with the malnutrition and proper nutrient category. Table 7 presents influential and noninfluencing variables.

Based on the value of multiple logistic coefficients of Kilensari and Gelung village, it can be concluded that the most influential variable on the nutritional status of children under five years is mother's knowledge with $\mathrm{p}=0.007(0.007<0.05)$. While the duration of breastfeeding, number of family members, family income does not affect the nutritional status of children under five years in Kilensari and Gelung village as a coastal area in Panarukan subdistrict, Situbondo regency. Respondents who have knowledge under average have a proper nutritional probability of 0.182 compared with respondents whose knowledge is above average. 
Table 7. Multiple Logistic Coefficient value of Kilensari and Gelung village

\begin{tabular}{|l|c|c|c|c|}
\hline Variabel & $\begin{array}{c}\text { Koef } \\
\text { (B) }\end{array}$ & Sig. & $\begin{array}{c}\text { Exp } \\
\text { (B) }\end{array}$ & Information \\
\hline $\begin{array}{l}\text { Duration } \\
\text { of } \\
\text { breastfee } \\
\text { ding }\end{array}$ & 0.644 & 0.320 & 1.904 & $\begin{array}{c}\text { Not } \\
\text { significant }\end{array}$ \\
\hline $\begin{array}{l}\text { Number } \\
\text { of family } \\
\text { member }\end{array}$ & 0.800 & 0.226 & 2.227 & $\begin{array}{c}\text { Not } \\
\text { significant }\end{array}$ \\
\hline $\begin{array}{l}\text { Family } \\
\text { income }\end{array}$ & -1.056 & 0.149 & 0.374 & $\begin{array}{c}\text { Not } \\
\text { significant }\end{array}$ \\
\hline $\begin{array}{l}\text { Mother's } \\
\text { knowledg } \\
\text { e }\end{array}$ & -1.705 & 0.007 & 0.182 & Significant \\
\hline Constants & 0.606 & $0 ., 91$ & 1.833 & - \\
\hline \multicolumn{5}{|c|}{ Source: Primary data (2017) } \\
\hline
\end{tabular}

\section{CONCLUSION}

1. Based on chi-square test of family income factor have an effect on the nutrition status of children under five years. In coastal areas like Kilensari and Gelung village, family income affects the nutritional status of children under five years. This is because most of its people work as fishermen with low income. At certain times the fishermen will sail to find fish but at times less supportive like big waves the fishermen will not find fish. So that will affect the income of the family and affect the fulfillment of food in terms of quality and quantity. Thus, the higher the family income level, the higher the fulfillment of nutritious and more varied foods such as vegetables, fruits, and otherwise the lower the family income, the less fulfillment and variety of food.

2. Based on the chi-square test and multiple logistic regression mother's knowledge factors affect the nutritional status of children. The fact in the field some of the mothers are less concerned about how to cook and process the food properly and less understood about the nutritional content of the food they eat. In Kilensari and Gelung village as coastal area lack of counseling about good nutrition for children under five years, and otherwise, if there is counseling some mother did not come for job reason. Thus, the higher the knowledge of a mother, the higher will be in receiving information about nutrition.

\section{ACKNOWLEDGMENT}

This research can be completed with the assistance of FISH UNESA through faculty policy funds in 2017.

\section{REFERENCES}

[1]

UNDP

Indonesia,

"www.id.undp.org/Indeks Pembangunan Manusia Indonesia M eningkat Tapi Kesenjangan Masih Tetap Ada," 14 April, 2017. [Online]. Available:

www.id.undp.org/Indeks_Pembangunan_Manusia_Indonesia_Me ningkat_Tapi_Kesenjangan_Masih_Tetap_Ada, diakses 4 April 2017. [Accessed: 14-Apr-2017].

[2] BPS Situbondo, "Kabupaten Situbondo Dalam Angka 2017." Situbondo, 2017.

[3] BPS Kecamatan Panarukan, "Laporan Statistik Kecamatan Panarukan." Situbondo, 2017.

[4] Sajogyo, Menuju Gizi Yang Merata Di Pedesaan Dan Di Kota. Yogyakarta: Gajah Mada University Press., 1980.

[5] Moehji, Ilmu Gizi. Jakarta: Bhatara, 1992.

[6] Suhardjo, Berbagai Cara Pendidikan Gizi. Jakarta: Bumi Aksara, 2003.

[7] B. \& Sayogyo, Peranana Gizi Dalam Pembangunan Nasiona. Jakarta: CV. Rajawali, 1986.

[8] A. Sediaoetama, Ilmu Gizi Untuk Mahasiswa dan Profesi Jilid I. Jakarta: Dian Rakyat, 2006. 